\title{
"Serious Enquiries Only, Please": Ethical Issues Raised by the Online Human Remains Trade
}

\author{
${ }^{1}$ Dr. Damien Huffer; ${ }^{2}$ Dr. Nathan Charlton \\ ${ }^{1}$ Department of Archaeology \& Classical Studies, Wallenberglaboratoriet, Lilla Frescativägen 7, \\ Stockholm University 114 18, Stockholm, Sweden. \\ ${ }^{2}$ Independent Scholar, Stockholm, Sweden.
}

\begin{abstract}
There is a thriving private commercial trade in anatomical, ethnographic and archaeological human remains that make ready use of new social media platforms such as Instagram, Facebook, Etsy, and until recently, eBay. This practice has deep Colonial-era roots, though the ongoing proliferation of e-commerce and social media has only expanded the reach and influence of collectors and dealers and their sense of community cohesion. In this chapter, we discuss a variety of ethical issues underlying this trade that speak to what the community values, how they operate, interrelate and interact with the scientific community. We ultimately seek to argue that participants in the trade engage with or ignore these complicating factors at their own risk, despite the ownership of human remains being legal in many jurisdictions once one's purchase has arrived.
\end{abstract}

\section{Defining the Problem}

There is a thriving private commercial trade in anatomical, ethnographic and archaeological human remains that make ready use of new social media such as Instagram, Facebook, Etsy, and until recently, eBay. This practice has deep roots as explorers, government officials and missionaries visited once remote peoples and began to collect, trade for, or acquire by other means, modified and unmodified human remains (e.g. Hose 1994; Roque 2010, 2011; Gosden and Knowles 2001; Legassick and Rassool 2000) but today's e-commerce has only expanded collector's reach. To date, very few nations or US states have introduced restrictions on the ownership, sale or transit of human remains (e.g. Marsh 2016), and most global legislation only defines what museums and Universities can or cannot do with human remains and related grave goods, whether from archaeological excavations or old Colonial-era collections (e.g. MárquezGrant and Fibiger 2011). At the same time, the shipment of cultural property consisting of, but not limited to human remains classifiable as cultural heritage, including archaeological or ethnographic specimens, are only infrequently apprehended.

Despite "terms of service" allegedly prohibiting the use of the most prominent social media platforms for illicit activities, numerous studies and exposés have revealed active trafficking of a wide range of prohibited goods, from drugs (Smith IV 2014), guns (Goel and Isaac 2016), to exotic animals (Haslett 2015). A wealth of literature exists pertaining to the use of datamining and social network analysis on new social media in general (e.g. Ferrara, Interdonato and Tagarelli 2014; Hernandez-Castro and Roberts 2015; Cavazos-Rehg et al. 2016; Moreno et al. 2016). However, exploration of the frequency and scope of the trade in cultural property, let alone human remains themselves, beyond auction house catalogs and the most common e- 
commerce platforms such as eBay is still in its infancy. The well-connected network of human remains collectors and dealers that constitute the online market are both specialist and generalist in their collecting focus (Huffer and Graham 2017). Furthermore, collectors and dealers have a surprisingly wide-reaching impact on the 'enthusiasts' who, through their rhetoric, support the activities of the community. The complicated antiquities and cultural property market that includes the trade in skeletal human remains has long been classified as a "grey market", but recent research is attempting to define the extent to which cultural property trafficking can be thought of as economically "grey"; i.e. not a legal, parallel, market for a given commodity, but rather a mixture of licit and illicit (Mackenzie and Yates 2017).

The skeletal human remains trade is itself a component of the larger "red market" (sensu Carney 2011) that traffics in living and dead human beings and their fresh or preserved tissues, including such disparate areas of research as corrupt adoption agencies (e.g. Riben 2015), the illicit organ trade, sources of bodies donated to medical education and research (e.g. Wordsworth 2015), corruption in blood donation and sale (e.g. Anand 2015), etc. Closer to the topic at hand, there exists separate overlapping markets for 'wet' specimens from hospitals, pathology laboratories, and separate collecting communities of artefacts from abandoned asylums, antique medical equipment, and 'murderabilia' (i.e. items once owned by, or art created by, famous serial killers, whether living or dead). Discussion of the entire "red market" is outside the scope of this chapter. Furthermore, we are not focused on related ethical debates over museum repatriation or how Universities assembled teaching collections in years past. The private commercial trade in human skeletal remains in its own right generates numerous ethical questions.

\section{The "Exotic" Dead as Curio, Commodity, and Cultural Property}

Understanding the online and offline commercial trade in human remains is, relatively speaking, a new area of research (e.g. Huxley and Finnegan 2004; Kubiczek and Mellon 2004; Nafte 2014, 2015; Huffer and Chappell 2014; Huffer and Graham 2017; Huffer et al. in press). Collectors and dealers in this 'niche' market have garnered their own attention in the popular press, given the esoteric and macabre nature of what they seek (e.g. Davis 2015; Gambino 2016). Individuals conduct transactions while based in numerous Western and non-Western countries and actively seek a variety of 'specimens.' These include allegedly authentic anatomical teaching specimens to mummies, "trophy" or "ancestral" skulls from Southeast Asian and Pacific Island cultures (e.g. the Dayak from Borneo, the Asmat from Irian Jaya, Sepik River tribes from Papua New Guinea, the Ifugao from Luzon, Philippines, various Solomon Islands groups, the Malekula and Ambrym cultures from Vanuatu, etc.) all classified as "tribal art" by collectors, as well as Tibetan Buddhist artefacts made from femora or tibiae, and old or contemporary items made from human bone or teeth, such as jewelry, knife handles, and canes.

As suggested above, collecting the dead of other cultures has been a human (not just Western) predilection prior to the era of Western colonial expansion. Taking skulls as war trophies is frequently observed in the historic and archaeological records, even if arguments for this practice are made via osteological evidence where written records are lacking or incomplete (e.g. Verano 2008; Tung 2008; chapters within Bonogofski 2011). A separate area of research concerns the analysis and repatriation of the skulls of fallen 'enemy' soldiers taken primarily during past American conflicts, especially WWII and the Vietnam War (e.g. Harrison 2006, 2012; Bass 1983; Sledzik and Ousley 1991; Weingartner 1992; Seidemann et al. 2009; Yucha et al. 2017). 
(more here re: a few refs about repatriation and museum controversies). As mentioned at the beginning of this section, academic work attempting to document and quantify commercial collecting, especially outside of religious or medical contexts (see Nafte 2014, 2015; Quigley 2001), is still quite rare.

Recent examples have garnered media attention due to the arguably shocking nature of the specimen being offered and the means of attempted sale (e.g. Killgrove, 2016). The majority of the media exposure that this trade has received comes after the fact, on those still-rare occasions that shipments are intercepted (e.g. Irfan 2015; ICE 2011; Wockner and Erviani 2016; O'Connor 2013; Radio Australia 2012). However, only very rarely have e-commerce platforms taken action in response to exposure and public outcry (Halling and Seidemann 2016; Kim 2012). Like other categories of licit and illicit commerce facilitated by social media, today's online market for human remains is facilitated by platform developers and actively manipulated by its users so as to exchange the real remains of the dead for money in an allegedly safe and "hidden" virtual space.

\section{Data acquisition methodology and research ethics}

As first discussed in Huffer and Graham (2017), Instagram was thoroughly queried between November 2015 and November 2016. A variation of a 'snowball' sampling strategy, beginning with known collections documented in previous research (Huffer et al. in press) was employed to identify some of the most common hashtags, including: \#humanbones, \#humanskulls, \#oddities, \#curiosities, \#realbone, and \#trophyskulls.

Several thousand photographs using Pablo Babera's 'InstaR' package (2015) were initially collected, adding to the data obtained through manual searching in Huffer et al. (in press). The 'InstaR' package allowed the searching of Instagram by hashtag, and downloading of the results. Instagram changed the way their public API worked in June 2016 such that only those seeking to commercialize users' data could access it in this way. A second package, this one written in PHP and which automated querying and paging through Instagram's public search page (Kapishev 2016) enabled us to continue exploring these posts, although with less rich metadata (see Graham 2016). In addition to the representative sample of at least the last three years' worth of posts already obtained, data collection by automated and manual methods on Instagram continues.

In regards to data collection on other platforms such as Marktplaats, relevant posts are screencaptured and saved by date, listed seller name or handle, and location. Collection of data on this platform only began in August 2017. Data from Facebook derives from three specific groups that we have accessed via a colleague, and includes post from $c .2015$ until present, with new data added regularly. Several new groups have sprung up since our research began, including those specific to a certain geographic region (e.g. the USA, the EU), or focused on specific niche topics (e.g. tsantsa, or "shrunken heads" produced by the Jivaro culture, Ecuador). A substantial degree of cross-posting occurs even just between the three groups actively monitored. When collecting data, a relevant post is screen-captured as it appears, labeled by date and name, and sorted by group and month. Effort is made to capture all image, text and metadata associated with any given post, divided into separate "parts" if more than one screen shot is required to capture the entire thread legibly. If more than one post is made by the same person on the same date, they are saved as (name) 1, (name) 2, etc. 
Across platforms, users often provide means of contacting them in their posts, and other information, such as geolocation data, zip codes, and emails addresses that could be used to identify them. While users may post information publicly in the hopes that prospective clients use it to arrange final sales privately, that is not the same thing as making them available for research. In one instance, a University ethics board (that of Carleton University, Ottawa, ON, Canada) ruled that data mining publically available social media was "research ethics exempt" in regards to research involving living human subjects (Huffer and Graham 2017). In other words, they represent public posts on social media deliberately made available to the public for purchase, or to garner appreciation of the extent of their collecting or raise interest in items that could be sold or traded if the price or exchange is right. Nevertheless, in the example figures provided below, we have continued the practice of blacking out all usernames to preserve anonymity.

\section{Buyer Beware?}

This section will present several examples drawn primarily from Instagram, Facebook and Marktplaats via the methods described in section 2.1 above. These examples provide visual and textual evidence illustrating how participants in the online human remains trade respond to or ignore certain ethical issues raised by the trade's existence and their participation in or active support of it. The topics chosen do not represent a comprehensive list of all possible ethical issues relating to the human remains trade facilitated by social media. The authors acknowledge this and have selected the following six general categories to explore some of the key ethical concerns and dilemmas that underpin the private commercial human remains trade. Individuals seeking to participate must therefore actively engage with these issues, or ignore them and put themselves at risk for being scammed or facing prosecution if items in transit to them are seized. The examples chosen as figures are only a few of many available within our current database, but were selected because they clearly illustrate each issue and how it is discussed, mitigated or ignored.

\subsection{False advertising and dishonest transactions}

We first turn to the topic of false advertising and implied dishonest transactions. By this, we mean a seller deliberately misleading a potential customer about the nature, source, age, or cultural authenticity of the remains being offered or knowingly defrauding each other. Research examining how antiquities in general are sold and the ability of forgeries to affect market demand has grown in recent years (e.g. Stanish 2009; Fay 2011, 2013; Brodie 2014, 2015; Scott 2013). However, to the best of our knowledge, research specifically addressing the prevalence or effect of false advertising on antiquities (let alone human remains) markets does not exist, most likely due to the difficulty of proving intentional false advertisement without having the item in question available for expert analysis. Global legislation also appears minimal, with protocols not specifically addressing the antiquities trade (Castendyke et al. 2008), or in the USA, only operating at state level (e.g. Frieden and Roche 2006). More research has been conducted, however, on issues of fraud, trust, and diversification in e-commerce (e.g. Gefen 2000; Turban et al. 2017; Xiao and Benbasat 2011).

At present, only eBay and Etsy have clear terms of service and policy that, on paper, prohibit the sale (or gifting) of all categories of human remains or material save scalp hair or, on Etsy, human teeth (eBay n.d.; Etsy 2017). As of writing, Instagram, Facebook or Marktplaats have not

followed suit. On Marktplaats at least, one needs only to list the human remains offered as "enkel voor studie-doeleinden" (only for study purposes), with no supporting documents or evidence to 
prove that either buyer or seller will comply (see Fig. 4.1.1). Stating this was necessary to sell human remains on eBay as well until new research and public pressure caused them to tighten and more readily enforce their policy (Vergano 2016). Figures 4.1.2 and 4.1.3 exemplify the tight-knit nature of the community, ready to name and shame purported scam artists and aid in resolving theft or dishonest transactions. Figures 4.1.4-4.1.6 attest to not only the continued attempted use of eBay as a sales platform and avenue for potential fraud, but also use collective opinion (for some born of decades of experience) to protect their own against fraud from within or without.

\subsection{Source country corruption and Customs violations}

Following on from this is the related issue of the extent to which collector and dealer demand for the best, most exotic or most macabre human remains fosters corruption within source countries or willing violation of (lax or inconsistent) Customs procedures. Here, we define 'source' countries as those, usually in the developing world, from which looted or smuggled cultural property derives (Brodie 2002) and consider the fostering of corruption to include collectors or dealers admitting to, and sometimes discussing the logistics of, shipping, as well as examples of 'composite' pieces that incorporate real skulls with vague or unstated provenance and provenience, suggesting the possibility of illicit export and import.

Figure 4.2.1 is a unique example of a 'composite' piece; a real skull sourced from somewhere in Indonesia, with decoration picked up elsewhere, made to look like a specimen of, in this case, Asmat cultural heritage. Even "fake" pieces will often incorporate real human bone, and our overall impression is that resin replicas are sought very rarely. Thus, the skull in question had to leave Indonesia by some means. The remaining figures (4.2.2-4.2.4) in this section give examples of discussions between collectors regarding their experience with shipping to or from various countries and how they have bypassed Customs or used the system to their advantage. Individuals mention false declarations, relative ease of shipping, shipping freshly exhumed specimens, and the varying degree to which different country's Customs officers look for or seize human remains. Examples such as these clearly illustrate that the risk and potential illegality of shipping or acquiring human remains is generally known, even if only sometimes openly acknowledged.

\subsection{Alleged complacency by the archaeological community}

This section provides examples that directly suggest complacency or involvement in furthering a collector's acquisitions by unidentified members of the archaeological community. Whether this occurred close to or well before the item's current owner acquired it is usually unknown.

Regardless, the trade or commerce implied would be in direct violation of every professional archaeological society's Code of Ethics (e.g. Society for American Archaeology n.d.;

Archaeological Institute of America 1997). Figures 4.3.1 and 4.3.2 illustrate two examples in which purchase from an archaeologist (or their spouse) at some point in the past is directly stated. Figure 4.3.1 is a Facebook post listing an alleged Incan skull of a "young girl" for sale, allegedly purchased in the 1970s from the widow of an individual who "went on archaeological digs around the world."

From the photos offered, the authors question the age and sex assessment provided by the seller, implying the possibility of false advertising as well. While it is always the story that sells the skeleton, Ecuador currently has state-ownership of all cultural patrimony, including excavated and still unexcavated material, with relevant legislation from 1945 (Salazar 1995) and has 
accepted or ratified all relevant UNESCO Conventions or Protocols. Figure 4.3.2 comes from Instagram, showing two mandibles, one of which "purchased from an archaeologist who found it on a dig ye(ars) ago". The seller appears based in the UK, but it is unclear where the mandibles come from or where the alleged excavation occurred. The ethical breach of practice implied by such collusion, if found to be true upon further investigation by law enforcement, would be severe. When already in private hands and sold through social media, however, the chance apprehending specimens such as these is minimal.

\subsection{Authenticity and validity through science}

Within the antiquities trade research community, significant concern is being raised over the extent to which scientific laboratories (from $\mathrm{C}^{14}$ dating to DNA analysis) might contribute to the trade by 'authenticating', analysing or conserving an item brought to them by a dealer (Argyropoulos et al. 2011; Brodie 2011; Caldararo 2000). In fact, an international conference was recently held at ETH Zurich from the $16^{\text {th }}-17^{\text {th }}$ November 2017, entitled "Radiocarbon dating and protection of cultural heritage - C14 Meeting". It focused in general on how laboratories can conduct better due diligence and more thoroughly query those who submit samples, especially individuals not affiliated with a University, museum, or cultural heritage management company (i.e. those most likely to be private collectors with sufficient finances). While the authors did not attend, discussion with colleagues who did suggests that the consensus opinion by delegates was of a much greater awareness of the problem, with more targeted codes of conduct for laboratory staff now being developed.

While this bodes well for an eventual end to the use of legitimate archaeological science as a means to commodify or directly threaten the archaeological record, Figures 4.4.1, 4.4.2 a and b, and 4.4.3 below show that, where the human remains trade is concerned, the problem remains. Figures 4.4.1 and 4.4.3 especially suggest that at least the occasional well-established or determined collector or dealer has the financial means and contacts necessary to arrange "tests" (likely radiocarbon dating) or purchase directly out of deaccessioned museum collections after specific analyses have been conducted. Figures 4.4.2 a and b, on the other hand, show the proprietor of the private Embody Museum (Embody Museum n.d.) offering advice to their Instagram followers regarding how to spot a fake Melanesian 'overmodeled' skull. The specific suggestion is made to seek out anthropologists and archaeologists for a final verdict, and the thread ends when one follower begins to ask more direct questions. We have yet to encounter a post containing information on who provided the alleged test, for what price, or what the results were, so it is possible that this information is shared only privately, if it occurred at all.

\subsection{Media complacency}

Stepping back from ethical concerns raised by the specificities of how the human remains trade operates and how buyers and sellers negotiate with each other, this section provides examples of instances in which public mass media was arguably complacent in encouraging the fetishization, commodification and no-questions-asked collecting of human remains. Figs 4.5.1 and 4.5.2 represent screen shots from just two of numerous examples available in which collectors and collecting is glamorized with little attention paid to legal or ethical concerns. The two examples below were both originally downloaded from YouTube.

Fig. 4.5.1. is a screen shot from the beginning of a video posted on April $6^{\text {th }}, 2017$. Entitled "human bones collector", the original poster is identifiable by name, but it is not clear if the main 
person seen removing a skeleton from what appears to be a recent burial is the same individual. Loud rap music accompanies the clip, and the looting is seen to be a team effort, with the dirty skeleton laid on the ground at the end so that posed pictures can be taken. This video was a chance discovery by the authors, but perfectly illustrates the infrequently seen beginning of the process by which "fresh" human remains could enter the market, either cleaned up and modified to look like something else (e.g. a cut anatomical specimen, a piece of "tribal art") or not. The video was reported to YouTube by the authors no more than two days after discovery, but to no effect.

Figure 4.5.2 is a striking example of higher-end media complacency. Taken from a news clip entitled "The Real Relic Hunter," by Global News out of Toronto, it follows a reporter through the condominium and collection of the late Bill Jamieson and his wife before his death on July $3^{\text {rd }}, 2011$, in the midst of shooting a mini-series about his life for History Television. In the news story mentioned above, Mr. Jamieson takes the opportunity to show off his immense collection of ethnographic artifacts and human remains, including mummies, tsantsa (shrunken heads), trophy skulls, etc. The reporter discusses how he (Mr. Jamieson, the interviewee) acquired the entire collection of the Niagra Falls Museum, how and why he collects, how his fame enhanced his collecting ability and public image, and how he has sold to several notable museums and other private collectors. After his death, his collection has been auctioned off, further reported on (Global News 2012; Bourgon 2011), and today continues to entice the collecting community (Fig. 4.5.3). More recent journalism (e.g. Hugo 2016a,b; Kilgrove 2016; Kukolja 2017) is beginning to ask tough questions and address legal and ethical complexities, but much remains to be done.

\subsection{Ethical and moral concerns as expressed by the collecting community}

Though many in the human remains collecting community attempt to distance themselves from those that desecrate the resting places of the deceased, and in turn show an apparent deep reverence for the dead, how much this sentiment actually translates to community self-policing to prevent illegality remains an open-ended question. Figure 4.6.1 represents a plea by a group administrator for members to know their laws and engage in "safe" business practices. Collectors, dealers or their supporters also sometimes present apparent concern or anger about news of cemeteries or mausoleums being vandalized or disturbed by development. Figure 4.6.2 illustrates group response to a member visiting the famous Paris Catacombs and the disrespect inherent in theft and resale from such a location.

Finally, figure 4.6.3 illustrated one individual's more whimsical use of their collection, tempered with the expressed hope that no one finds it disrespectful. They are included specifically to demonstrate that the community overall is not entirely indifferent towards how society at large might conceive of, use or violate the dead. Thus, while community members might express a wide range of ethical and moral opinions to justify their collecting and their relation to the dead themselves, the examples above, to us, also imply commodification fueled by substantial cognitive dissonance.

\section{Is the Human Remains Trade "Wrong"?}

In this section we use the examples given and the significance of the issues raised to discuss a fundamental question: Is the human remains trade (in its modern form) "wrong"? To put it another way, should the public at large be concerned with the existence of this trade and thus 
expend the time and energy required pressure the key social media/e-commerce platforms to reform terms of service and better enforce use? 'Normative' ethics in the context of business practices "implicitly regulates areas and details of behavior that lie beyond governmental control" (Berle and Means 1932). A wide variety of unethical and/or criminal activities facilitated by social media have attracted the attention of ethicists and law enforcement (e.g. Vallor 2015; Kelly 2012). While the antiquities trade overall has been dismissed as a 'victimless' crime (Yates 2016; Bowman Proulx 2011; Mackenzie 2006, 2011a), where the "objects" being trafficked are human remains, this is a difficult position to maintain.

Beyond the visceral disgust that most feel when exposed to burial looting in action by accident or via news reports (Jamir 2017; Hicks 2016; WTAE-TV Pittsburgh 2013), or when especially disturbing Customs seizures are reported during or after the hand-back ceremony (e.g. ICE 2011), the majority of the trade passes under the radar, hiding in plain sight. The human remains trade is exists as its own complex 'grey market' (Mackenzie and Yates 2017, 2016), mixing legal and illegal, authentic and fake. Recent research and reporting (Kukolja 2017; Huffer and Chappell 2014; Huffer et al. in press) has begun to question the legality of selling or owning human remains with vague provenance and provenience and ample evidence that the community acknowledges this. The extent to which relevant paperwork proving legal import, export, or residence outside of source countries before UNESCO or State-specific cultural property legislation is exchanged through private direct messaging or email is unknown. While we acknowledge that this could occur at least occasionally, especially where recent anatomical specimens are concerned, the lack of transparency and potential for criminality that e-commerce can foster should give anyone pause for concern.

Among archaeologists, the ethical dilemmas inherent in the online trafficking of cultural property have been raised before at the highest levels of the archaeological discipline (e.g. Barker 2000), very little action has been taken by the social media companies themselves to change the ease with which unethical and questionably illicit sales (of many products) can be conducted. It is this ability for small-scale collectors to readily use social media and the community it fosters to conduct clandestine sales or exchange tips about shipping or specimen conservation that can negate the ethical concerns of 'enthusiasts' seeking to begin collecting. Those few high-profile collectors who have been interviewed naturally take a different approach when questioned about the underbelly of the trade. One, quoted in Davis (2015), said: "We're respectful, we're not making fun of it. We love this stuff, we hold it up on a pedestal." Many would also argue that, since collectors almost exclusively seek the dead of "others", not necessarily named individuals or their own relatives, they are doing nothing inherently wrong. The examples presented here suggest otherwise.

\section{Is an Ethical Private Human Remains Trade Possible?}

The examples discussed above and what they suggest about the underpinnings of the human remains trade are meant more to illustrate issues that need to be further investigated so that criminologists, archaeologists and law enforcement can more effectively understand and monitor activities and prosecute cases when seizures occur and professional osteological assessments made. In lights of the above, we conclude by discussing whether an ethical private commercial trade is even possible.

In a 2015 article for Vice (Hunter 2015), the author, a self-described "ethical collector of human bones and other weird stuff", describes numerous criteria they personally use to source the bones 
they buy, their take on the nature of the allegedly licit and admittedly illicit market $c .2015$, and other topics. Specifically discussing the ethical stance they take to justify collecting, they state:

"Because of my beliefs, I only buy bones that I can touch. That's right, no Internet deals for me. You might feel like you need to ask the bones' permission to bring them home, and that's just fine. I've never held a bone that felt gross or angry to me, but I'm sure they're out there. I treat my bones with a lot of reverence and respect, and they're a really positive part of my home.

Personally, I steer clear from bone fetishism or using my bones as tools. I don't flaunt skulls to guests as a status symbol or use them as seasonal decor. I'd never drink wine or serve candies out of a skull, because that's super impolite in my book. Also, you're risking the ingestion of bio-hazardous human remains or noxious chemicals. The ethics of bone collecting definitely extends into display and use, and it's something that you ought to reflect on...As a concept, it's currently at a pretty weird place in our cultural framework, where it's equal parts trendy fad and offensive horror."

It is probable that this ever-evolving trade will continue to find new avenues as social media platforms proliferate (and, with the exception of Ebay and Etsy, do not attempt to clearly constrain human remains or antiquities trading in their "terms of service"). In fact, we have recently encountered individuals making reference to items for sale, or their own purchases, on Facebook Marketplace, as yet unexplored. Other much more widely used e-commerce platforms such as Craigslist sometimes continue to host ads seeking or selling human remains, which at times have also received media coverage (Yee 2017). Monitoring the online trade also reveals very little about that portion occurring off-line, so knowing its full extent and frequency in realtime is probably not possible. As recent exposes (Stevenson 2017) continue to suggest, "there are no international legal protections, no "obligations of ownership", for cultural property in private possession. More broadly, the legal status of these sales confers an air of legitimacy to the antiquities trade." These concerns are amplified where human remains are concerned, given the finite supply of real specimens, alleged connection to the archaeological and museum community (even if only in decades past), and increased reliance on very open-ended new social media.

Hunter (2015) concludes by asking: "Is collecting bones the right thing to do? Honestly, I'm still not entirely certain. I'll probably never know, but I'll keep working on it." As we have suggested, it does not appear that the human remains collecting community at large is giving due consideration to how participation in, or support of, their particular hobby (or for some, their livelihood) can foster unethical or immoral behavior. The level of due diligence performed by collectors and dealers is not uniform and will likely change with increasing public exposure of (and reaction to) what lies beneath the readily-manipulatable new "face" of the trade outside of traditional auction houses or brick-and-mortar stores. The expectation of any antiquities collecting community to "self-regulate" has been readily questioned (e.g. Mackenzie 2004). Given the slow pace of change to or standardization of cultural property or e-commerce legislation between countries (and US states), the risk of deliberate or accidental ethical and legal breaches will continue to be the foundation on which this so-called 'victimless crime' rests.

\section{References}

Anand A. 2015. Blood for sale: India's illegal 'red market'. The BBC. http://www.bbc.com/news/business-30273994. [Accessed 14 September 2017]. 
Archaeological Institute of America 1997. Code of Ethics. Archaeological Institute of America. https://www.archaeological.org/news/advocacy/130 [Accessed 28 November 2017].

Argyropoulos V., Polikreti K., Simon S., Charalambous D. 2011. Ethical issues in research and publication of illicit cultural property. Journal of Cultural Heritage 12: 214-219.

Barbera P. 2015. 'instaR: access to Instagram API via R', v0.2.0. Github. https://github.com/pablobarbera/instaR/releases. [Accessed 24 November 2017].

Barker A.W. 2000. Ethics, e-commerce, and the future of the past. Society for American Archaeology. http://www.saa.org/portals/0/saa/publications/saabulletin/18-1/saa13.html [Accessed 24 November 2017].

Bass W.M. 1983. The occurrence of Japanese trophy skulls in the United States. Journal of Forensic Sciences 28: 800-803.

Berle A.A. and Means G.C. 1932. The Modern Corporation and Private Property. Transaction Publishers: New Jersey.

Bonogofski M. (Ed.) 2011. The Bioarchaeology of the Human Head. University Press of Florida: Tallahassee.

Brodie N. 2002. Illicit antiquities. In: Brodie N. and Tubbs K.W. (eds.) Illicit Antiquities: The Theft of Culture and the Extinction of Archaeology. Routledge: London, pp. 1-22.

Brodie N. 2011. Congenial bedfellows? The academy and the antiquities trade. Journal of Contemporary Criminal Justice 27: 408-437.

Brodie N. 2014. The internet market in Pre-Columbian antiquities. In: Kila J.D. and Balcells M. (eds.) Cultural Property Crime: An Overview and Analysis of Contemporary Perspectives and Trends. Brill: Leiden, pp. 237-262.

Brodie N. 2015. The internet market in antiquities. In: Desmarais F. (Ed.) Countering Illicit Traffic in Cultural Goods: The Global Challenge of Protecting the World's Heritage. ICOM: Paris.

Bourgon L. 2011. Bill Jamieson was a treasure-hunting rarity. The Globe and Mail. https://www.theglobeandmail.com/arts/television/bill-jamieson-was-a-treasure-huntingrarity/article4260507/ [Accessed 28 November 2017].

Bowman Proulx, B. A. 2011a. Drugs, arms, and arrowheads: Theft from archaeological sites and the dangers of fieldwork. Journal of Contemporary Criminal Justice 27: 500-522.

Caldararo N. 2000. Fake or transitional form? Analysis of a purported Pre-Columbian Olmec artifact and comparison with similar published objects from Mesoamerica. Mexicon 22: 58-63.

Carney S. 2011. The Red Market: On the Trail of the World's Organ Brokers, Bone Thieves, Blood Farmers, and Child Traffickers. Harper Collins: New York. 
Castendyke O., Dommering E., Scheuer A., Böttcher K. (eds.) 2008. European Media Law. Amsterdam: Kluwer Law International.

Cavazos-Rehg P.A., Krauss M.J., Sowles S.J., and Bierut L.J. 2016. Marijuana-related posts on Instagram. Prevention Science 17: 710-720.

Davis S. 2015. Meet the living people who collect dead human remain. Vice. http://www.vice.com/read/meet-the-living-people-who-collect-human-remains-713. [Accessed 24 November 2017].

Ebay n.d. Human remains and body parts policy. Ebay. http://pages.ebay.com/help/policies/ remains.html [Accessed 30 November 2017].

Embody Museum n.d. Exhibition of ethnographic studies \& visual arts. INK361. http://ink361.com/app/users/ig-1275941987/embodymuseum/photos [Accessed 28 November 2017].

Etsy 2017. Prohibited items policy. Etsy. https://www.etsy.com/legal/prohibited/\#Q2 [Accessed 30 November 2017].

Fay E.V. 2011. Virtual artifacts: eBay, antiquities, and authenticity. Journal of Contemporary Criminal Justice 27: 449-464.

Fay E.V. 2013. Trading in antiquities on eBay: the changing face of the illicit trade in antiquities. Unpublished PhD dissertation, School of Criminology and Sociology, Keele University, UK.

Ferrara E., Interdonato R., Tagarelli A. 2014. Online popularity and topical interests through the lens of Instagram. Proceedings of the $25^{\text {th }}$ ACM conference on Hypertext and social media, pp. 24-34.

Frieden J.D., Roche S.P. 2006. E-commerce: Legal issues of the online retailer in Virginia. Richmond Journal of Law \& Technology 13: 1-16.

Gambino P. (Ed.) 2016. Morbid Curiosities: Collections of the Uncommon and Bizarre. London: Laurence King Publishing.

Gefen D. 2000. E-commerce: the role of familiarity and trust. Omega 28: 725-737.

Global News 2012. Preview of Treasure Trader premier. YouTube. https://www.youtube.com/watch?v=WWIt-iYiG8A [Accessed 28 November 2017].

Goel V., Isaac M. 2016. New Facebook policy bans talk of private gun sales, applies to Instagram. The New York Times. http://www.nytimes.com/2016/01/30/technology/facebook-gunsales-ban.html?_r=0. [Accessed 2 October 2017].

Gosden C., Knowles C. (eds.), 2001. Collecting colonialism: Material culture and colonial change. Berg Publishers, Inc.: Oxford. 
Halling C.L., Seidemann R.M. 2016. They sell skulls online?! A review of internet sales of human skulls on eBay and the laws in place to restrict sales. Journal of Forensic Sciences 61: 1322-1326.

Harrison S. 2006. Skull trophies of the Pacific War: Transgressive objects of remembrance. Journal of the Royal Anthropological Institute 12: 817-836.

Harrison S. 2012. Dark Trophies: Hunting and the Enemy Body in Modern War. Berghahn Books: New York.

Haslett C. 2015. Click to like this: is Instagram a hub for illegal ape deals? Mongabay. http://news.mongabay.com/2015/12/click-to-like-this-is-instagram-a-hub-for-illegal-ape-deals/ [Accessed 14 November 2017].

Hicks E. 2016. Grave robbing for morons. You Tube. https://www.youtube.com/watch?v=GgAQuvtttk. [Accessed 14 November 2017].

Hose C. 1994. Fifty Years of Romance and Research in Borneo. Oxford University Press: Oxford.

Huffer D., Chappell D. 2014. The mainly nameless and faceless dead: an exploratory study of the illicit traffic in archaeological and ethnographic human remains. Crime, Law, and Social Change 62: 131-53.

Huffer D., Chappell D., Charlton N. and Spatola B. in press. Bones of contention: the online trade in archaeological, ethnographic and anatomical human remains on Instagram. In: Chappell D. and Hufnagel S. (Eds.) Art Crime Handbook, Palgrave Macmillan Press: London.

Huffer D., Graham S. 2017. The Insta-Dead: The rhetoric of the human remains trade on Instagram. Internet Archaeology, doi: http://intarch.ac.uk/journal/issue45/5/index.html.

Hugo K. 2016a. You probably don't understand the laws about selling body parts. BU News Service. http://bunewsservice.com/you-probably-dont-understand-the-laws-about-selling-bodyparts/ [Accessed 28 November 2017].

Hugo K. 2016b. Human skulls are being sold online, but is it legal? National Geographic. https://news.nationalgeographic.com/2016/08/human-skulls-sale-legal-ebay-forensics-science/ [Accessed 28 November 2017].

Hunter L. 2015. It happened to me: I'm an ethical collector of human bones and other weird stuff. Vice. https://www.xojane.com/it-happened-to-me/how-to-buy-human-bones-ethically [Accessed 14 November 2017].

Huxley A.K., Finnegan M. 2004. Human remains sold to the highest bidder! A snapshot of the buying and selling of human skeletal remains on eBay®, an internet auction site. Journal of Forensic Science 49: 1-4. 
ICE 2011. ICE returns tribal artifacts to Indonesian authorities.

https://www.ice.gov/news/releases/ice-returns-tribal-artifacts-indonesian-authorities. [Accessed 20 September 2017].

Irfan A. 2015. Indonesian government to investigate report on human skull smuggling. Antara News. http://www.antaranews.com/en/news/99239/indonesian-government-to-investigate-reporton-human-skull-smuggling [Accessed 14 November 2017].

Jamir I. 2017. Human bones collector. You Tube. https://www.youtube.com/watch?v= i9TnqahuNbw [Accessed 14 November 2017].

Kapishev R. 2016. 'instagram-php-scraper' v0.4.5. Github. https://github.com/postaddictme/instagram-php-scraper/releases?after=v0.4.5.

Kelly H. 2012. Police embrace social media as crime-fighting tool. CNN.com http://edition.cnn.com/2012/08/30/tech/social-media/fighting-crime-social-media/index.html [Accessed 30 November 2017].

Killgrove K. 2016. Mummy crowdfunder leaves archaeologists fuming. Forbes. http://www.forbes.com/sites/kristinakillgrove/2016/10/10/mummy-crowdfunder-leavesarchaeologists-fuming/\#115d303f1d2d. [Accessed 13 November 2017].

Kim E. 2012. Etsy blocks sales of drugs and human remains. CNN Money. http://money.cnn.com/2012/08/10/technology/etsy-bans-drugs/index.html [Accessed 14 November 2017].

Kubiczek P.A., Mellen P.F. 2004. Commentary on: Huxley A.K. and Finnegan, M., Human remains sold to the highest bidder! A snapshot of the buying and selling of human skeletal remains on eBay, an internet auction site. Journal of Forensic Science 49: 17-20.

Kukolja K. 2017. Fighting trade in human remains antiquities. The Saturday Paper. https://www.thesaturdaypaper.com.au/2017/10/21/fighting-trade-human-remainsantiquities/15085044005381 [Accessed 14 November 2017].

Legassick M., Rassool C. 2000. Skeletons in the cupboard: South African museums and the trade in human remains 1907-1917. South African Museum: Cape Town.

Mackenzie S. 2006. Psychosocial balance sheets: Illicit purchase decisions in the antiquities market. Current Issues in Criminal Justice 18: 221-241.

Mackenzie S. 2011a. The market as criminal and criminals in the market: Reducing opportunities for organised crime. In: Manacorda S. and Chappell D. (Eds.) Crime in the Art and Antiquities World. New York: Springer, pp. 69-85.

Mackenzie S. 2014. Dig a bit deeper: Law, regulation and the illicit antiquities trade. The British Journal of Criminology 45: 249-268. 
Mackenzie S., Yates D. 2017. What is grey about the "grey market" in antiquities? In: Beckert, J. and Dewey, M. (Eds.) The Architecture of Illegal Markets: Towards an Economic Sociology of Illegality in the Economy. Oxford University Press: Oxford, pp. 70-87.

Mackenzie S., Yates D. 2016. Collectors on illicit collecting: Higher loyalties and other techniques of neutralization in the unlawful collecting of rare and precious orchids and antiquities. Theoretical Criminology 20: 340-357.

Márquez-Grant N., Fibiger L. (eds.), 2011. The Routledge Handbook of Archaeological Human Remains and Legislation. Routledge Press: London.

Marsh T. 2016. The Law of Human Remains. Lawyers and Judges Publishing Company, Wake Forest Univ. Legal Studies Paper No. 2646184.

Moreno M.A., Ton A., Selkie E., Evans Y. 2016. Secret Society 123: Understanding the language of self-harm on Instagram. Journal of Adolescent Health 58: 78-84.

Nafte M. 2015. Institutional bodies: Spatial agency and the dead. History and Anthropology 26: 206-233.

Nafte M. 2014. Trophies and Talismans: The Traffic of Human Remains. Unpublished PhD dissertation, McMaster University, Hamilton, Ontario, Canada.

O'Connor M. 2013. Italian arrested 'for smuggling human skulls into Asia.' The Telegraph. http://www.telegraph.co.uk/news/worldnews/africaandindianocean/burundi/10436673/Italianarrested-for-smuggling-human-skulls-into-Asia.html. [Accessed 15 September 2017].

Quigley C. 2001. Skulls and Skeletons: Human Bone Collections and Accumulations. McFarland \& Company, Inc.: London.

Radio Australia 2012. PNG police investigate claims of human skull exports. Radio Australia. http://www.radioaustralia.net.au/international/2005-01-20/png-police-investigate-claims-ofhuman-skull-exports/778700. [Accessed 24 November 2017].

Riben M. 2015. Adoption criminality and corruption. The Huffington Post. https://www.huffingtonpost.com/mirah-riben/adoption-crimes-and-corru_b_6467540.html. [Accessed 10 October 2017].

Roque R. 2010. Headhunting and Colonialism: Anthropology and the circulation of human skulls in the Portuguese Empire, 1870-1930. Palgrave Macmillan: Hampshire, UK.

Roque R. 2011. Stories, skulls, and colonial collections. Configurations 19: 1-23.

Salazar E. 1995. Between crisis and hope: Archaeology in Ecuador. Society for American Archaeology Bulletin 13: 34-37.

Scott D.A. 2013. Modern antiquities: The looted and the faked. International Journal of Cultural Property 20: 49-75. 
Smith IV J. 2014. Here's every statistic you could want on Instagram drug dealers. http://observer.com/2014/05/heres-every-statistic-you-could-want-on-instagram-drug-dealers/.

Seidemann R.M., Stojanowski C.M., Rich F.J. 2009. The identification of a human skull recovered from an eBay sale. Journal of Forensic Sciences 54: 1247-1253.

Sledzik P., Ousley S. 1991. Analysis of six Vietnamese trophy skulls. Journal of Forensic Science 36: 520-530.

Society for American Archaeology n.d. Principles of archaeological ethics. Society for American Archaeology. http://www.saa.org/AbouttheSociety/PrinciplesofArchaeologicalEthics/tabid/ 203/Default.aspx [Accessed 28 November 2017].

Stanish C. 2009. Forging ahead: Or, how I learned to stop worrying and love eBay. Archaeology 62: 23-28.

Stevenson A. 2017. Why archaeological antiquities should not be sold on the open market, full stop. The Conversation. http://theconversation.com/why-archaeological-antiquities-should-notbe-sold-on-the-open-market-full-stop-54928 [Accessed 29 November 2017].

Tung T.A. 2008. Dismembering bodies for display: A bioarchaeological study of trophy heads from the Wari site of Conchopata, Peru. American Journal of Physical Anthropology 136: 294308.

Turban E., Outland J. King D., Lee J.K., Liang T.-P., Turban D.C. (eds.) 2017. Electronic Commerce 2018: A Managerial and Social Networks Perspective, $9^{\text {th }}$ edition. Springer: Cham, Switzerland.

Vallor S. 2015. Social networking and ethics. Stanford Encyclopedia of Philosophy. https://plato.stanford.edu/entries/ethics-social-networking/\#SocNetSerCyb [Accessed 30 November 2017].

Verano J.W. 2008. Trophy head-taking and human sacrifice in Andean South America. In: Silverman H. and Isbell W.H. (eds.) The Handbook of South American Archaeology, Springer: New York, pp. 1047-1060.

Vergano D. 2016. eBay just nixed its human skull market. BuzzFeed News. https://www.buzzfeed.com/danvergano/skull-sales?utm_term=.qarND3vxQ\#.wvxqo8DkP [Accessed 30 November 2017].

WTAE-TV. 2013. Nearly 200-year-old grave dug up. You Tube. https://www.youtube.com/ watch? $\mathrm{v}=\mathrm{n} 2 \mathrm{EXUo} 2 \mathrm{~A} 72 \mathrm{w}$. [Accessed 14 November 2017].

Weingartner JJ. 1992. Trophies of war: U.S. troops and the mutilation of Japanese war dead, 1941-1945. Pacific Historical Review 61: 53-67.

Wockner C, Erviani K. 2016. Police in Bali discover human skull en route to Australia. News.com.au. http://www.news.com.au/national/crime/police-in-bali-discover-human-skull-en- 
route-to-australia/news-story/a865399a6bb885475cfe76e8c579f9c4. [Accessed 14 November 2017].

Wordsworth R. 2015. A shortage of legitimate donors is fueling the black market organ trade. Vice. https://motherboard.vice.com/en_us/article/8q8ajp/the-false-choice-of-the-black-marketorgan-trade. [Accessed 21 November 2017].

Xiao B., Benbasat I. 2011. Product-related deception in e-commerce: a theoretical perspective. MIS Quarterly 35: 169-196.

Yates D. 2016. The global traffic in looted cultural objects. In: Pontell H. N. (ed.) Oxford Research Encyclopedias: Criminology and Criminal Justice. Oxford University Press: New York doi:10.1093/acrefore/9780190264079.013.124.

Yee G. 2017. 'Human skull WANTED': Why a Charleston resident posted this year's spookiest Craigslist ad. The Post \& Courier. http://www.postandcourier.com/news/human-skull-wantedwhy-a-charleston-resident-posted-this-year/article_94586a38-bc11-11e7-895d67974e10b47f.html. [Accessed 21 November 2017].

Yucha JM, Pokines JT, Bartelink EJ. 2017. A comparative taphonomic analysis of 24 trophy skulls from modern forensic cases. Journal of Forensic Sciences 62: 1266-1278. 